\title{
Are epiphytes a significant component of intertidal Zostera noltii beds?
}

\author{
Benoit Lebreton ${ }^{a},{ }^{\star}$, Pierre Richard ${ }^{a}$, Gilles Radenac ${ }^{a}$, Monique Bordes $^{b}$, Martine Bréret ${ }^{a}$, \\ Christophe Arnaud ${ }^{\mathrm{c}}$, Françoise Mornet ${ }^{\mathrm{c}}$ and Gérard F. Blanchard ${ }^{\mathrm{a}}$
}

\footnotetext{
a UMR Littoral, Environnement et Sociétés (LIENSs), UMR 6250 CNRS-Université de La Rochelle, Institut du Littoral et de l'Environnement, 2 rue Olympe de Gouges, 17042 La Rochelle, France

${ }^{b}$ Centre Commun d'Analyses, FR EDD 3097 CNRS-Université de La Rochelle, 5 allée de l'Océan, 17071 La Rochelle Cedex 9, France

c UMS Environnement Littoral Atlantique (ELA), UMS 3109 CNRS-IFREMER, Place Gaby Coll, BP 5, 17137 L'Houmeau, France
}

*: Corresponding author: B. Lebreton, Tel.: +33 5465076 41; fax: +33 5465076 63, email address : benoit.lebreton@univ-Ir.fr

\begin{abstract}
:
The role of epiphytes in an intertidal Zostera noltii seagrass bed in Marennes-Oléron Bay was assessed in comparison with the other main benthic primary producers (Z. noltii, microphytobenthos) at two bathymetric levels and on a seasonal basis. Assemblage and biomass of epiphytes were studied using scanning electron microscopy (SEM). Z. noltii and its detrital matter followed a typical seasonal pattern: microphytobenthos was present in large quantities throughout the year representing $21 \%$ of the total biomass while detrital matter, above-ground parts and below-ground parts accounted for 65,9 and 5\%, respectively. Only two species of epiphytic diatoms, Cocconeis scutellum and Cocconeis placentula, were observed on seagrass leaves. Epiphyte biomass was very low, representing on average less than $0.001 \%$ of that of microphytobenthos or leaves. This low epiphyte biomass is linked with the absence of macroalgae and also with the low biovolume of Cocconeis, which formed a monolayer of cells on leaves. This can be explained by the severe conditions of the intertidal and the high leaf turn-over of $Z$. noltii leaves.
\end{abstract}

Keywords: Primary producer; Intertidal seagrass bed; Zostera noltii; Microphytobenthos; Epiphyte diatom; Cocconeis spp.; SEM

\section{Introduction}

Because of its low palatability, seagrass material is generally not directly consumed by invertebrate grazers but mostly enters the detrital food web (Cebrián and Duarte, 1998; Cebrián, 1999). Invertebrate grazers thus depend more on micro- and macro-algae present in these systems. From the many studies done on seagrass food webs, on numerous seagrass species and locations, the paradigm has emerged that epiphytic algae constitutes the most important primary producer supporting the invertebrate food web in seagrass beds (Kitting et al., 1984; Moncreiff et al., 1992; Moncreiff and Sullivan, 2001; Borowitzka et al., 2006; Hoshika et al., 2006). Zostera noltii (Hornemann, 1832) is a mono-meristematic leaf-replacing and fast-growing seagrass species (Duarte, 1991; Short and Duarte, 2001) occurring along European coasts. It inhabits the upper parts of mudflats, generally above Zostera marina (Linné, 1753) when both species are found in the same seagrass bed (Marbà et al., 1996; Moore and Short, 2006). Z. noltii is frequently found in intertidal areas where it can be exposed to long periods of emersion and to strong tidal currents. Many studies have been conducted to measure the 


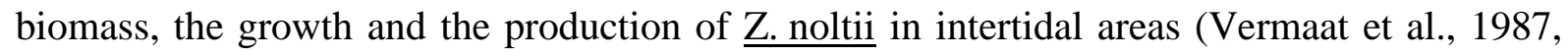
1993; Pérez-Lloréns and Niell, 1993; Philippart, 1995a; Auby and Labourg, 1996; Marbà et al., 1996; Vermaat and Verhagen, 1996; Brun et al., 2003). But few authors have attempted to

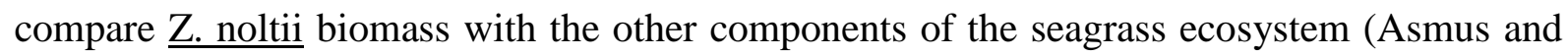
Asmus, 1985; 2000). Doing so, it turns out that the epiphytic biomass associated with $\underline{\text { Z. noltii }}$ leaves in intertidal areas is low (Hootsmans et al., 1993; Philippart, 1995b; Schanz et al., 2002) compared to what is usually observed in seagrass beds from subtidal habitats (Borowitzka et al., 2006). In these ones, epiphytic algae contribute on average more than 30 $\%$ of the total above-ground biomass.

The present study was undertaken to check whether the low epiphytic biomass can be considered as a specific feature of the intertidal habitat and also to identify the possible causes of this observed feature. We quantified and compared the different benthic primary producers in an intertidal seagrass bed, focusing on the structure and the biomass of epiphytes. An annual survey of the biomass of the three benthic autotrophic components ( $\underline{Z}$. noltii, microphytobenthos and epiphytic algae) and of detrital matter was carried out at two bathymetric levels of a seagrass bed situated in Marennes-Oléron Bay (France). A surficial mapping of epiphyte distribution on shoots was performed seasonally using SEM to estimate epiphytic biomass.

\section{Materials and methods}

\subsection{Study site}

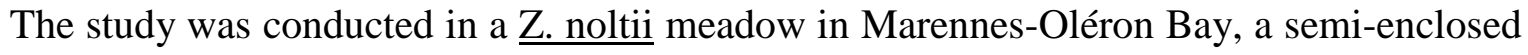
system along the French Atlantic coast $\left(45^{\circ} 54^{\prime} \mathrm{N}, 1^{\circ} 12^{\prime} \mathrm{W}\right)$. This macrotidal bay (tidal range 2.4-5.1 m), located between Oléron Island and the mainland, receives continental water inputs mainly from the Charente River whose flow ranges from 15 to $500 \mathrm{~m}^{3} \mathrm{~s}^{-1}$ (Ravail et al., 1988). 
Due to the heavy particulate matter load of the river (annual mean $1 \mathrm{~g} \mathrm{~L}^{-1}$ ), suspended matter concentrations are generally high in the bay, as a mean above $50 \mathrm{mg} \mathrm{L}^{-1}$ (Struski, 2005). The seagrass bed is located on the western side of the bay, along Oléron Island, more strongly influenced by offshore marine waters (Dechambenoy et al., 1977). In the bay, tidal current speeds range from 0.04 to $0.27 \mathrm{~m} \mathrm{~s}^{-1}$ (Struski, 2005). The Zostera bed extends over $15 \mathrm{~km}$ along the shore and is $1.5 \mathrm{~km}$ wide in the upper part of the flat, limited in its lower part by extensive oyster farm structures (Guillaumont, 1991).

Two sampling stations have been studied: a high flat station (HFS) and a low flat station (LFS), located at about $250 \mathrm{~m}$ from the upper and lower limits of the seagrass bed, respectively, and $1 \mathrm{~km}$ apart from each other. Each station was a homogeneous area of $100 \mathrm{~m}^{2}$ (50 $\mathrm{m} \times 2 \mathrm{~m}$, i.e. 100 plots of $1 \mathrm{~m}^{2}$ ) parallel to the coastline. Both stations emerged during every low tide, but there were about 5 additional hours of emersion at the upper station.

\subsection{Sampling of Zostera noltii and detrital matter}

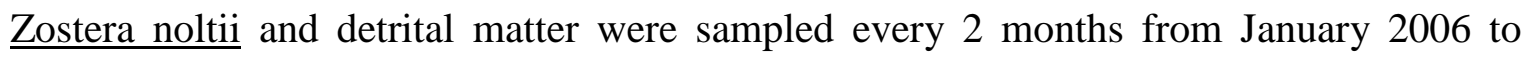
January 2007. On both stations, four cylindrical cores $\left(280 \mathrm{~cm}^{2}, 15 \mathrm{~cm}\right.$ deep) were randomly collected. The core surface area was determined according to the study of Pérez-Llorenz and Niell (1993), and the number of replicates was determined during a preliminary sampling following the method of Sfriso and Ghetti (1998), that aims at assessing the accuracy and the precision of the mean as a function of the sampling cost.

The sediment was gently sieved through a $500 \mu \mathrm{m}$-mesh in the laboratory with tap water and whole sieve retained by the mesh was frozen at $-20^{\circ} \mathrm{C}$ until further analysis. After thawing, shoot density was estimated for each sample unit. Leaves of 60 randomly selected shoots were measured to the nearest mm (Auby and Labourg, 1996) to estimate total leaf length and total leaf surface per square meter (leaf area index, LAI, $\mathrm{m}^{2} \mathrm{~m}^{-2}$ ), by using leaf 
width measured by SEM (see Section 3.2). The seagrass material was then sorted and divided into above-ground parts: all green leaves, and below-ground parts: rhizomes and associated roots. Rhizomes were considered alive when crispy and light brown or ivory white (Philippart, 1995a). All other material was considered as detrital matter. Samples were then freeze-dried and weighed.

For both above-ground and below-ground biomasses and each sampling period, three aliquots were ground to a powder using a ball mill and an accurate mass (0.4-1.2 mg \pm 0.001 mg) was packed in tin capsules. Sample carbon content was determined using an elemental analyzer (Euro EA 3024, EuroVector, Milan, Italy).

Non-parametric tests were used because of the dependence of data (temporal data) and of the small size of samples: Wilcoxon bilateral two-sample tests for paired samples to compare station data and Kruskal-Wallis tests to compare temporal data.

\subsection{Observation and quantification of epiphytes on Zostera leaves}

To quantify the relationship between epiphytes and Zostera leaves, we decided to avoid methods that could affect epiphyte distribution and abundance on leaves, such as scraping or chemical extraction (Dauby and Poulicek, 1995). Preliminary tests of epiphyte scraping were attempted but this method appeared not feasible to our samples, mainly because of the slimness of leaves (Moore and Short, 2006). Therefore, epiphytic diatoms were directly

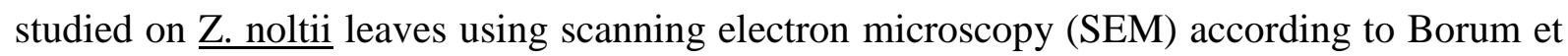
al. (1984) and Mazzella et al. (1995).

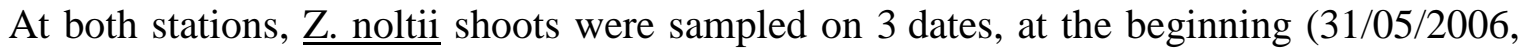
spring), the middle (6/09/2006, summer) and the end (9/11/2006, fall) of the vegetative period. No sampling was done in winter because of the almost complete absence of $\underline{Z}$. noltii shoots. In the field, entire shoots of $\underline{Z}$. noltii were collected randomly and fixed in a $4 \%$ 
formaldehyde-seawater solution (Jacobs and Noten, 1980; Reyes et al., 1998). In the laboratory, 2 shoots with intact leaves were randomly selected for each station. As the growth rate of Zostera leaves is likely to affect the distribution and abundance of epiphytes (Borum et al., 1984), 3 leaves per shoot were observed, when possible: the smallest one (youngest), the longest one (oldest) and the medium one. For each leaf, surficial mapping of epiphytes was performed along transects corresponding to the width of the leaves at 4 levels equally distributed between the point of insertion of the blade-sheath (transect 1) and the leaf apex (transect 4), adapted from Borum et al. (1984) and Reyes et al. (1998). Since the leaf growth occurs at the blade-sheath, transect 1 represents the youngest part of the leaf, and transect 4 the oldest.

Leaves were rinsed in distilled water (Mazzella et al., 1995), slightly dried on one face using a filter paper and glued directly to the specimen holder using a double-face carbon sticky ribbon, without metallization. Observations were carried out using a Philips/FEI microscope Quanta 200 ESEM/FEG equipped with an EDAX system. It was operated at 20 $\mathrm{kV}$ in environmental mode at a water vapor pressure of 1 mbar in the specimen chamber.

Each transect was fully examined to account for a possibly irregular transversal

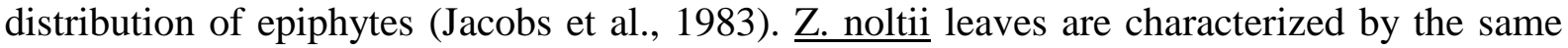
structure on both faces (Kuo and Den Hartog, 2001), so we observed only one face per leaf assuming that there was no difference in epiphyte structure between both faces such as demonstrated with Zostera marina (Jacobs et al., 1983), Cymodocea nodosa (Reyes and Sansón, 1997) and Posidonia australis (Trautman and Borowitzka, 1999). For each transect, the width and the height were measured $(\mu \mathrm{m})$.

Epiphytes were counted and measured (length and width) along the whole transect using an image analysis software. Four cell types were defined: "intact cells", "broken cells", "intact hypovalves" and "broken hypovalves". Each intact cell was identified at the species 
level when feasible (Round et al., 1990; Rincé, 1993). For biomass estimations, a length to height ratio of 10:1 was used (Van den Brink et al., 1997) and the biovolume (V) of each cell was estimated using the formula: $\mathrm{V}=\pi / 4 \times \mathrm{L} \times \mathrm{W} \times \mathrm{H}$, depending on length (L), width (W) and height (H) (Hillebrand et al., 1999). The biovolume (V) to carbon biomass per cell (pgC cell${ }^{1}$ ) ratio was determined using the relationship $\mathrm{pgC}^{-1}=0.288 \times \mathrm{V}^{0.811}$ (Menden-Deuer and Lessard, 2000). Epiphyte biomass was estimated per season and per station using these carbon biomass values, epiphyte densities and total leaf lengths per square meter (see Section 2.2), that have been multiplied by 2 to consider both leaf sides.

Distribution of epiphytes (intact cells, broken cells and intact hypovalves) among leaves (oldest, medium and youngest) and among transects was studied using density data. KruskalWallis tests were applied to compare distributions among transects on oldest leaves and among leaves on oldest transects (transect 4). Differences between means were determined with the Dunn procedure for multiple comparisons with Bonferroni correction.

\subsection{Sampling of microphytobenthos}

Microphytobenthos samplings were carried out every 2 months from July 2006 to May 2007 on both stations, using a sampling strategy defined in a former local study (Guarini et al., 1998). Accordingly, five cores of $181 \mathrm{~cm}^{2}$ were randomly taken, and the top $1 \mathrm{~cm}$ of the sediment was collected. The sediment was carefully mixed and an aliquot was gently sieved

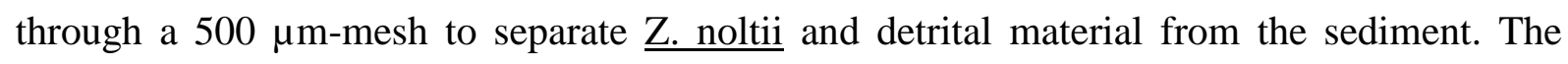
sieved sediment was then freeze-dried and kept in the dark at $-20^{\circ} \mathrm{C}$ until further analysis. Pigment content of the sediment was extracted in $90 \%$ acetone during one night in the dark with agitation at $4^{\circ} \mathrm{C}$; chlorophyll a was then measured using the fluorometric method (Lorenzen, 1966). Chlorophyll $\underline{\mathrm{a}}$ values were converted into carbon biomass using the 
conversion factor (47.63) established by De Jonge (1980). The same non-parametric statistics were applied to compare stations and temporal data as above.

\section{Results}

3.1 Annual cycle of Zostera noltii, microphytobenthos and detrital matter biomass

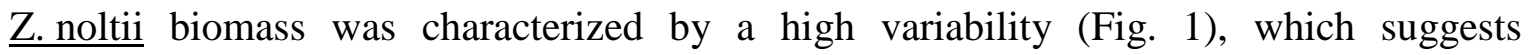
considerable patchiness in the field. We found no difference in above-ground part biomass, below-ground part biomass and detrital matter between HFS and LFS (Wilcoxon tests, aboveground parts: V-value: 207, p-value: 0.107 ; below-ground parts: V-value: 170, p-value: 0.584, detrital matter: V-value: 193, p-value: 0.229). We did find a significant difference for microphytobenthos with a higher biomass at HFS (Wilcoxon test, V-value: 109, p-value: 0.010). Detrital matter was the main organic material in the seagrass bed accounting on average for $65 \%$ of the organic mass. Microphytobenthos, above-ground and below-ground parts on average accounted for 21, 9 and $5 \%$ of total biomass, respectively (Fig. 1).

Above-ground parts biomass was characterized by a significant seasonal pattern (Table 1). Its mean biomass ranged from a minimum of $0.2 \mathrm{~g} \mathrm{C} \mathrm{m}^{-2}$ (LFS, January 2007) to a maximum of $8.1 \mathrm{~g} \mathrm{C} \mathrm{m}^{-2}$ (HFS, July 2006). The growth phase of above-ground parts occurred mainly between March and May, with a ca. 6- to 7-fold increase in HFS and LFS, respectively. Then above-ground parts biomass was steady between May and July and slightly decreased from September to January (Fig. 1). Leaf surface was strongly correlated with above-ground parts biomass $\left(r^{2}\right.$ HFS $=0.82, r^{2}$ LFS $\left.=0.84\right)$ and followed the same seasonal pattern at both stations. Between winter and summer, leaf surface area increased by a factor of 15.9 and 51.3 at HFS and at LFS, respectively. Z. noltii leaf area index was higher than the sediment surface area at HFS in July with $1.0 \mathrm{~m}^{2}$ of leaves per $\mathrm{m}^{2}$ of flat (Fig. 1). 
Below-ground parts biomass showed less seasonal influence than above-ground parts biomass. It was much more constant throughout the year with mean values ranging from $0.4 \mathrm{~g}$ $\mathrm{C} \mathrm{m}^{-2}$ (LFS, November 2006) to $4.6 \mathrm{~g} \mathrm{C} \mathrm{m}^{-2}$ (LFS, July 2006) (Fig. 1). A seasonal significant variation occurred only at LFS (Table 1).

Detrital matter, mainly composed of dead rhizomes and roots, showed a strong seasonal pattern (Table 1) with the highest biomass in September (50.4 $\mathrm{g} \mathrm{C} \mathrm{m}^{-2}$ at HFS), representing the ending period of seagrass growth, and the lowest in January $2006\left(10.2 \mathrm{~g} \mathrm{C} \mathrm{m}^{-2}\right.$ at HFS) (Fig. 1).

For microphytobenthos biomass, there was no seasonal pattern at HFS (Table 1) with a mean biomass ranging from $8.0 \mathrm{~g} \mathrm{C} \mathrm{m}^{-2}$ (November 2006) to $14.5 \mathrm{~g} \mathrm{C} \mathrm{m}^{-2}$ (January 2007) (Fig. 1). At LFS, values were comprised between 5.7 (November 2006) and $10.3 \mathrm{~g} \mathrm{C} \mathrm{m}^{-2}$ (September 2006) (Fig. 1).

\subsection{Diversity and biomass of epiphytes}

For the three seasons (spring, summer and fall) and at both sampling stations, neither

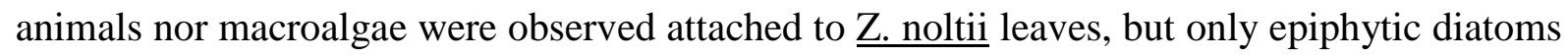
belonging to two species: Cocconeis scutellum (Ehrenberg) and Cocconeis placentula (Ehrenberg) (Fig. 2). A total of 16, 909 diatom items was counted and measured from 112 leaf transects: 48 in spring and summer, 16 in fall (one leaf per shoot).

All cells were adherent to the leaves by the hypovalve (raphe valvar side) and thus formed a homogeneous unicellular layer on the leaf. Due to this type of attachment, many single hypovalves were found alone on Zostera leaves. This layer could also include sediment or detrital matter stuck on exopolysaccharides and could form a crust covering the leaf entirely (Fig. 2). 
Most items were intact diatoms (from 54 to $72 \%$ depending on station and season), identified from 70 to $94 \%$ of them, depending on their position on the leaves. From 70 to 94 $\%$ of intact cells were identified. Other items were intact hypovalves (5-26\%), broken hypovalves (4-19\%) and broken cells (2-14\%) (Table 2).

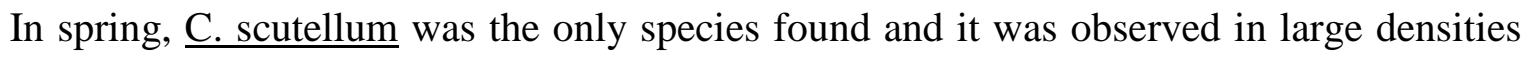

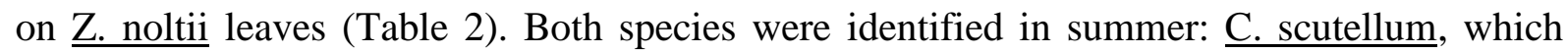

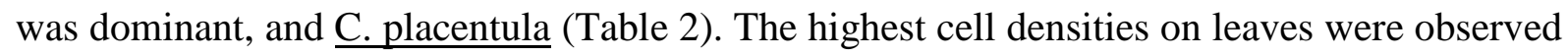
in summer, with 5025 (HFS) and 1913 (LFS) cells $\mathrm{mm}^{-2}$ of leaf (Table 2). In fall, $\underline{\text { C. scutellum }}$ again represented almost the entire epiphyte population on Zostera leaves.

The mean cell biovolume was highly variable depending on seasons and stations; standard deviations were also very high (Table 3). Cell biovolumes ranged from $46.37 \mu \mathrm{m}^{3}$ (HFS, summer 2006) to $168.37 \mu \mathrm{m}^{3}$ (HFS, fall 2006). The biomass of epiphytes was very low with values ranging from 0.09 (fall, LFS) to $3.97 \mathrm{mg} \mathrm{C} \mathrm{m}^{-2}$ (summer, HFS) (Table 3). Epiphytic biomass was always lower than $0.001 \%$ of that of microphytobenthos or leaves (Table 3).

\subsection{Microdistribution of epiphytes along Zostera noltii leaves}

Microdistribution of cell densities was studied along the oldest leaf (all transects) and among oldest transects (transects 4 on oldest, medium and youngest leaves) (Fig. 3). Data from the 3 seasons were pooled and the single leaves sampled in fall were considered as the oldest ones.

On the oldest leaf, mean densities ranged from 65 (transect 1) to 1234 (transect 3) cells $\mathrm{mm}^{-2}$ (Fig. 3A) and a significant difference was observed between transect 1 (youngest) and the three oldest ones (Kruskal-Wallis test, K-value: 16.776, p-value: 0.001). The same pattern of distribution was observed among leaves on the oldest transect (Fig. 3B). Mean densities ranged from 238 cells $\mathrm{mm}^{-2}$ (youngest leaves) to 994 cells $\mathrm{mm}^{-2}$ (medium leaves) and a 
difference was observed between densities on youngest and on oldest leaves (Kruskal-Wallis test, K-value: 5.699, p-value: 0.058).

\section{Discussion}

\subsection{Seasonal variation of Zostera noltii biomass}

Above-ground and below-ground parts biomass of $\underline{\mathrm{Z}}$; noltii showed a strong patchiness due to in-situ microtopography and clonal patchiness, possibly (Laugier et al., 1999; Brun et al., 2003). At a larger scale, no difference was observed between HFS and LFS, showing no influence of emersion time on the biomass dynamics of $\underline{Z}$. noltii.

Above-ground parts biomass measured in Marennes-Oléron Bay was very low, such as previously found by Pigeot (2001), with maximum values between 2.5 and 6.1 times lower than what is usually observed on European coasts, as reviewed by Auby and Labourg (1996). This is likely due to the high turbidity of water in the bay (Héral et al., 1983).

Temporal variations of above-ground parts biomass showed a strong seasonal pattern, typical of temperate seagrasses (Duarte, 1989) and of Z. noltii (Pérez-Lloréns and Niell, 1993; Philippart, 1995a; Auby and Labourg, 1996; Vermaat and Verhagen, 1996; Sfriso and Ghetti, 1998; Pergent-Martini et al., 2005). It might have a strong influence on epiphytes biomass because it directly determines the leaf surface availability for epiphytes colonization; the leaf surface area was thus multiplied by 51.3 at HFS and by 15.9 at LFS between winter and summer. However, the maximum leaf surface available per $\mathrm{m}^{2}$ stays relatively low for $\underline{\mathrm{Z}}$. noltii as shown by the maximum leaf area index exceeding $1 \mathrm{~m}^{2} \mathrm{~m}^{-2}$ only in July at HFS, whereas LAI could range from around 0.3 to $6.6 \mathrm{~m} \mathrm{~m}^{-2}$ in Z. noltii (Van Lent et al., 1991; Plus et al., 2001; Pergent-Martini et al., 2005) and from around 1 to 5 and 4 to $8 \mathrm{~m}^{2} \mathrm{~m}^{-2}$ all year long in Z. marina and Posidonia oceanica, respectively (Guidetti et al., 2002). 
In fall, the biomass loss of above-ground parts was related to the slowdown of $\underline{\mathrm{Z}}$. noltii growth (Duarte, 1989; Philippart, 1995a; Marbà et al., 1996), to leaf shedding (Cebrián et al., 1997), but also to the heavy grazing by the migrant Brent geese (Branta bernicla L.) (Poisbleau, 2005).

Below-ground parts biomass exhibited a weak seasonal pattern in Marennes-Oléron Bay. As for above-ground parts, maximum biomass values were lower (from 1.6 to 13.1 times) than in other European seagrass beds (Auby and Labourg, 1996). Below-ground parts biomass mainly accumulated in the sediment after death (Bach et al., 1986; Cebrián et al., 1997), thus explaining the increase in detrital matter observed until September. The amount of detrital matter in the sediment was ten times higher than above-ground parts biomass, thus constituting a large stock of organic matter available for detritivores and decomposers (Harrison, 1989). The decrease in detrital matter observed in fall can be explained by decomposition processes and the decrease of detrital input due to the slowdown of seagrass growth.

\subsection{Importance of microphytobenthos}

The maximum microphytobenthic biomass was observed in the upper part of the intertidal flat, in agreement with previous observations on the same site (Guarini et al., 1998), but there was no seasonal pattern. Recorded values of biomass were among the highest reported in several reviews (Colijn and De Jonge, 1984; Daehnick et al., 1992; MacIntyre et al., 1996) on subtidal and intertidal sandflats, mudflats and seagrass beds (Table 4). Most importantly, microphytobenthic biomass exhibited values of the same order of magnitude as above-ground parts biomass in summer, thus representing an important source of organic matter all year long. 
High rates of microphytobenthic production are usually found in seagrass beds (Mateo et al., 2006), but only few comparisons with other primary producers are available. On an intertidal Zostera bed in the Wadden Sea, Asmus and Asmus $(1985 ; 2000)$ estimated that microphytobenthos production contributes to 19 and to $54 \%$, respectively, of the total primary production. Asmus and Asmus (2000) estimated that production of microphytobenthos was dominant with $347 \mathrm{~g} \mathrm{C} \mathrm{m}^{-2} \mathrm{yr}^{-1}$ vs. $258 \mathrm{~g} \mathrm{C} \mathrm{m}^{-2} \mathrm{yr}^{-1}$ for Zostera. On other subtidal seagrass beds, relative contributions ranged from 5 to $42 \%$ (Table 4).

\subsection{Epiphytes: comparison with other seagrass bed components}

Comparison between the biomass of epiphytes and that of other components of the seagrass bed shows that epiphytes represent a very low biomass all year long, less than $0.001 \%$ of above-ground parts or microphytobenthic biomass. Only diatoms of the genus $\underline{\text { Cocconeis }}$ were observed during our annual survey and they usually colonize only a fraction of the leaf surface area, with a biomass ranging from 0.09 to $3.97 \mathrm{mg} \mathrm{C} \mathrm{m}^{-2}$.

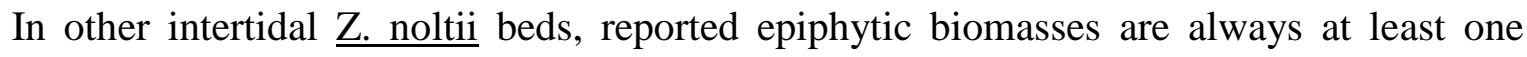
order of magnitude higher than those found in Marennes-Oléron Bay. Thus, in the Wadden Sea, Asmus and Asmus (1985) showed that epiphytic diatoms can represent in summer approximately $0.01 \%$ of the leaf biomass of $\underline{Z}$. noltii, and can reach a higher biomass than microphytobenthos. However, on an annual basis, they estimated that epiphytes represent 2.7 $\%$ of the total biomass of primary producers. In the Wadden Sea, Philippart (1995b) showed that epiphyte biomass represented approximately between 0.05 and $0.20 \%$ of the leaf biomass.

Based on these data, there is evidence that epiphytes play a minor role in intertidal $\underline{\mathrm{Z}}$. noltii beds, a conclusion that is strongly in opposition with most studies dealing with subtidal habitats (Morgan and Kitting, 1984; Moncreiff et al., 1992; Lepoint et al., 2000; Moncreiff 
and Sullivan, 2001; Hoshika et al., 2006) where epiphytic algae contribute to more than $30 \%$ of the total above-ground biomass (Borowitzka et al., 2006) and are as the main source of organic matter for primary consumers, particularly invertebrate grazers (Kitting et al., 1984; Moncreiff and Sullivan, 2001; Hily et al., 2004).

\subsection{Why is epiphyte biomass low?}

The first reason for a low epiphytic biomass is that neither animals nor macroalgae were

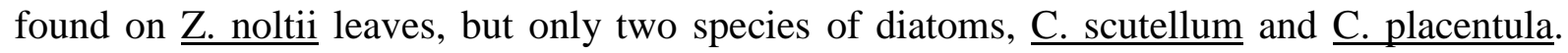
Our study is thus strongly in opposition with most studies on epiphytes diversity, which generally report a high species richness for seagrass epiphytes, from unicellular algae to large macrophytes (Jacobs and Noten, 1980; Jacobs et al., 1983; Heijs, 1985; Borowitzka et al., 1990; Mazzella et al., 1995; Reyes et al., 1998; Borowitzka et al., 2006). This absence of

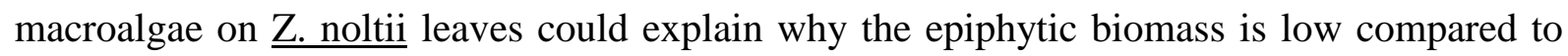
other seagrass species on which macroalgae are common. This is confirmed by the study of

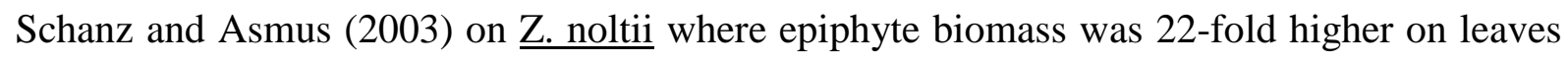
with macroalgae compared to leaves without macroalgae.

The second reason is that Cocconeis are small diatoms with a length ranging from 5 to 25 $\mu \mathrm{m}$. These cells are strongly adherent to the leaves by the hypovalve (Round et al., 1990; Mazzella et al., 1995) and our observations based on SEM clearly show that they form a biofilm at the surface of Zostera leaves. This biofilm was always composed of a monolayer of cells with a maximum thickness of $2.5 \mu \mathrm{m}$ - Cocconeis have a length to height ratio of 10:1, (Van den Brink et al., 1997) - when Van Montfrans et al. (1982) found a biofilm with a thickness of $15 \mu \mathrm{m}$ and 3 to 4 layers of diatoms on $\underline{\mathrm{Z} \text {. marina. }}$

\subsection{Why only Cocconeis?}




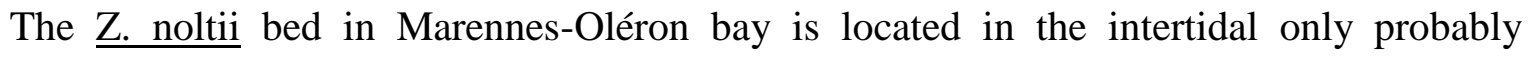
because of the high turbidity of the water column. As a consequence, the seagrass bed is subject to large variation in environmental parameters. During high tides, the high water turbidity largely limits light penetration for photosynthesis. During low tides, $\underline{\text { Z. noltii }}$ epiphytes are exposed to desiccation and to rapid variations and extreme values of temperature, light intensities or salinity. This severe environment can negatively affect the diversity and biomass of epiphytes found on intertidal seagrass leaves (Main and McIntire, 1974; Hootsmans et al., 1993). The impact of emersion was partially confirmed because, in the very rare tidal pools in the field, the development of Licmophora sp. or Pylaeilla littoralis, was observed sometimes on Zostera leaves, whereas none was observed on leaves from emerged areas.

The fast turn-over of $\underline{\mathrm{Z}}$. noltii leaves, as shown by a leaf production rate of 107 leaves $\operatorname{shoot}^{-1}$ year $^{-1}$ and a leaf plastochrone interval of 3.4 days leaf $^{-1}$ (Duarte, 1991), is also likely to have an influence on the very low epiphytic diversity such as demonstrated by Borowitzka et al. (2006). These authors showed that the more persistent seagrass species tend to have a greater epiphytic biomass with a more diverse assemblage. The short life span of Zostera noltii leaves would thus prevent more species to colonize and thus would select for pioneer species such as the genus Cocconeis (Sieburth and Thomas, 1973; Borum et al., 1984; Kitting et al., 1984; Lethbridge et al., 1988), particularly the species Cocconeis scutellum which is widespread (Harlin, 1980; Jacobs and Noten, 1980; Van Montfrans et al., 1982; Mazzella et

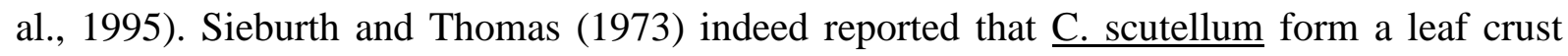
that could be a necessary step prior to the attachment of other epiphytes on leaves. In the present study, we can thus interpret the monospecific epiphytic biofilm as the result of the leaf

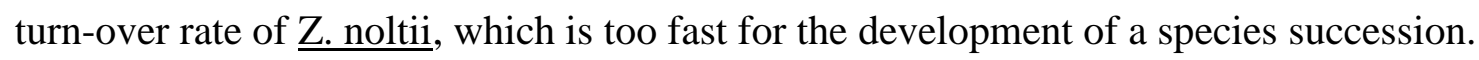


The rapid growth of Zostera leaves and its influence on epiphyte diversity and biomass is also supported by the analysis of the microdistribution of cells on leaves which clearly shows that cell density tends to increase with the age of leaves on individual shoot. This trend is in agreement with previous observations (Jacobs et al., 1983; Borum, 1987; Reyes et al., 1998; Borowitzka et al., 2006).

Another explanation of the exclusive presence of Cocconeis could be grazing pressure. Epiphyte communities are subject to a top-down control by herbivores which have an effect not only on biomass but also on the structure of epiphyte assemblages (Van Montfrans et al., 1982, 1984; Orth and Van Montfrans, 1984; Jernakoff et al., 1996; Sommer, 2000; Schanz et al., 2002). Diatoms of the genus Cocconeis, that are firmly attached cells, reportedly resist grazing and are less consumed than other diatoms, e. g. Nitzschia, Amphora (Van Montfrans et al., 1982) or macroalgae (Mazzella and Russo, 1989), thus increasing their frequency (Van Montfrans et al., 1982). Despite of the presence of grazers, such as Hydrobia ulvae (656118,328 ind. $\mathrm{m}^{-2}$ ), Littorina littorea $\left(17-123 \underline{\text { ind. } \mathrm{m}^{-2}}\right.$ ) and Idotea chelipes $\left(13-103 \underline{\text { ind. } \mathrm{m}^{-2}}\right.$ ), in the seagrass bed of the Marennes-Oléron Bay, grazing pressure seems to be low. Indeed, on the few tidal pools present in the study area, where Hydrobia ulvae densities were even higher (Lebreton, pers. obs.), development of other epiphytic species (Licmophora sp., $\underline{\text { P. littoralis) }}$ was sometimes observed. Influence of grazing on epiphyte assemblages was likely limited compared to the effect of intertidal conditions and the fast growth of $\underline{Z}$. noltii.

So, this intertidal seagrass bed is characterized by the very low quantitative importance of epiphytes, compared to the other primary producers, and by their very low diversity. Indeed, epiphyte biomass observed in the Marennes-Oléron Bay turns out to be the lowest recorded value. The very low epiphyte diversity and biomass measured in this study are therefore likely due to the severe physical characteristics from the intertidal mudflat and seagrass biological characteristics. Disentangling physical from biological parameters that control epiphytes 
development would need more work, for instance through comparisons between intertidal and subtidal environments

\section{Acknowledgements}

This study forms part of the Ph.D. thesis of B.Lebreton. This work was financially supported by the 'Ministère de l'Enseignement Supérieur et de la Recherche' and the programmes 'ACI Ecologie quantitative' and 'Programme National d'Environnement Côtier'. The authors thank G. Guillou for elemental analyses, P. Pineau, T. Guyot, J. Pigeot, D. Vilday for their help during field samplings and F. Paticat for S.I.G. computing. B.Lebreton thanks Y. Rincé and I. Auby for their helpful advices and the team of the 'Réserve naturelle nationale de Moëze-Oléron'.

\section{References}

Asmus, H., Asmus, R., 1985. The importance of grazing food chain for energy flow and production in three intertidal sand bottom communities of the northern Wadden Sea. Helgol. Meeres. 39, 273-301.

Asmus, H., Asmus, R., 2000. Material exchange and food web of seagrass beds in the SyltRømø Bight: how significant are community changes at the ecosystem level? Helgol. Mar. Res. 54, 137-150.

Auby, I., Labourg, P.-J., 1996. Seasonal dynamics of Zostera noltii Hornem. in Bay of Arcachon (France). J. Sea Res. 35, 269-277.

Bach, S.D., Thayer, G.W., LaCroix, M.W., 1986. Export of detritus from eelgrass (ostera marina) beds near Beaufort, North Carolina, USA. Mar. Ecol. Prog. Ser. 28, 265-278. 
Borowitzka, M.A., Lethbridge, R.C., Charlton, L., 1990. Species richness, spatial distribution and colonisation pattern of algal and invertebrate epiphytes on the seagrass Amphibolis griffithii. Mar. Ecol. Prog. Ser. 64, 281-291.

Borowitzka, M.A., Lavery, P.S., Van Keulen, M., 2006. Epiphytes of seagrasses. In: Larkum, A.W.D., Orth, R.J., Duarte, C.M. (Eds.), Seagrasses: Biology, Ecology and Conservation. Springer, Dordrecht, pp. 441-461.

Borum, J., 1987. Dynamics of epiphyton on eelgrass (Zostera marina L.) leaves: relative roles of algal growth, herbivory, and substratum turnover. Limnol. Oceanogr. 32, 986-992.

Borum, J., Kaas, H., Wium-Andersen, S., 1984. Biomass variation and autotrophic production of an epiphyte-macrophyte community in a coastal Danish area. 2. Epiphyte species composition, biomass and production. Ophelia 23, 165-179.

Brun, F.G., Pérez-Lloréns, J.L., Hernández, I., Vergara, J.J., 2003. Patch distribution and within-patch dynamics of the seagrass Zostera noltii Hornem. in Los Toruños SaltMarsh, Cádiz Bay, Natural Park, Spain. Bot. Mar. 46, 513-524.

Cebrián, J., 1999. Patterns in the fate of production in plant communities. Am. Nat. 154, 449468.

Cebrián, J., Duarte, C.M., 1998. Patterns in leaf herbivory on seagrasses. Aquat. Bot. 60, 6782.

Cebrián, J., Duarte, C.M., Marbà, N., Enríquez, S., 1997. Magnitude and fate of the production of four co-occuring Western Mediterranean seagrass species. Mar. Ecol. Prog. Ser. 155, 29-44.

Colijn, F., De Jonge, V.N., 1984. Primary production of microphytobenthos in the EmsDollard estuary. Mar. Ecol. Prog. Ser. 14, 185-196.

Daehnick, A.E., Sullivan, M.J., Moncreiff, C.A., 1992. Primary production of the sand microflora in seagrass beds of Mississipi sound. Bot. Mar. 35, 131-139. 
Dauby, P., Poulicek, M., 1995. Methods for removing epiphytes from seagrasses: SEM observations on treated leaves. Aquat. Bot. 52, 217-228.

De Jonge, V.N., 1980. Fluctuations in the organic carbon to chlorophyll a ratios for estuarine benthic diatom populations. Mar. Ecol. Prog. Ser. 2, 345-353.

Dechambenoy, C.L., Pontier, F., Sirou, F., Vouvé, J., 1977. Apport de la thermographie infrarouge aéroportée à la connaissance de la dynamique superficielle des estuaires (système Charente-Seudre-Anse de l'Aiguillon). C. R. Acad. Sci. Paris 284, 12691272.

Duarte, C.M., 1989. Temporal biomass variability and production/biomass relationships of seagrass communities. Mar. Ecol. Prog. Ser. 51, 269-276.

Duarte, C.M., 1991. Allometric scaling of seagrass form and productivity. Mar. Ecol. Prog. Ser. 77, 289-300.

Guarini, J.-M., Blanchard, G.F., Bacher, C., Gros, P., Riera, P., Richard, P., Gouleau, D., Galois, R., Prou, J., Sauriau, P.-G., 1998. Dynamics of spatial patterns of microphytobenthic biomass: inferences from a geostatistical analysis of two comprehensive surveys in Marennes-Oleron Bay (France). Mar. Ecol. Prog. Ser. 166, 131-141.

Guidetti, P., Lorenti, M., Buia, M.C., Mazzella, L., 2002. Temporal dynamics and biomass partitioning in three Adriatic seagrass species: Posidonia oceanica, Cymodocea nodosa, Zostera marina. P.S.Z.N.: Marine Ecology 23, 51-67.

Guillaumont, B., 1991. Utilisation de l'imagerie satellitaire pour des comparaisons spatiales et temporelles en zone intertidale. In: Elliott, M., Ducrotoy, J.-P. (Eds.), Estuaries and Coasts: Spatial and Temporal Intercomparisons. ECSA 19 Symposium. Olsen \& Olsen, pp. 63-68. 
Harlin, M.M., 1980. Seagrass epiphytes. In: Phillips, R.C., McRoy, C.P. (Eds.), Handbook of Seagrass Biology: An Ecosystem Perspective. Garland STPM Press, New York, pp. 117-151.

Harrison, P.G., 1989. Detrital processing in seagrass systems: a review of factors affecting decay rates, remineralization and detritivory. Aquat. Bot. 23, 263-288.

Heffernan, J.J., Gibson, R.A., 1983. A comparison of primary production rates in Indian River, Florida seagrass systems. Fla. Sci. 46, 295-306.

Heijs, F.M.L., 1985. The seasonal distribution and community structure of the epiphytic algae on Thalassia hemprichii (Ehrenb.) Aschers. from Papua New Guinea. Aquat. Bot. 21, 295-324.

Héral, M., Razet, D., Deslous-Paoli, J.-M., Berthomé, J.-P., Garnier, J., 1983. Caractéristiques saisonnières de l'hydrobiologie du complexe estuarien de Marennes-Oléron (France). Rev. Trav. Inst. Pêches marit. 46, 97-119.

Hillebrand, H., Dürselen, C.D., Kirschtel, D., Pollingher, U., Zohary, T., 1999. Biovolume calculation for pelagic and benthic microalgae. J. Phycol. 35, 403-424.

Hily, C., Connan, S., Raffin, C., Wyllie-Echeverria, S., 2004. In vitro experimental assessment of the grazing pressure of two gastropods on Zostera marina L. ephiphytic algae. Aquat. Bot. 78, 183-195.

Hootsmans, M.J.M., Vermaat, J.E., Beijer, J.A.J., 1993. Periphyton density and shading in relation to tidal depth and fiddler crab activity in intertidal seagrass beds of the Banc d'Arguin (Mauritania). Hydrobiologia 258, 73-80.

Hoshika, A., Sarker, M.J., Ishida, S., Mishima, Y., Takai, N., 2006. Food web analysis of an eelgrass (Zostera marina L.) meadow and neighbouring sites in Mitsukuchi Bay (Seto Inland Sea, Japan) using carbon and nitrogen stable isotope ratios. Aquat. Bot. 85, 191-197. 
Jacobs, R.P.W.M., Noten, T.M.P.A., 1980. The annual pattern of the diatoms in the epiphyton of eelgrass (Zostera marina L.) at Roscoff, France. Aquat. Bot. 8, 355-370.

Jacobs, R.P.W.M., Hermelink, P.M., Van Geel, G., 1983. Epiphytic algae on eelgrass at Roscoff, France. Aquat. Bot. 15, 157-173.

Jensen, P.R., Gibson, R.A., 1986. Primary production in three subtropical seagrass communities: a comparison of four autotrophic components. Fla. Sci. 49, 129-141.

Jernakoff, P., Brearley, A., Nielsen, J., 1996. Factors affecting grazer-epiphyte interactions in temperate seagrass meadows. Oceanogr. Mar. Biol. Ann. Rev. 34, 109-162.

Kaldy, J.E., Onuf, C.P., Eldridge, P.M., Cifuentes, L.A., 2002. Carbon budget for a subtropical seagrass dominated coastal lagoon: how important are seagrasses to total ecosystem net primary production? Estuaries 25, 528-539.

Kitting, C.L., Fry, B., Morgan, M.D., 1984. Detection of inconspicuous epiphytic algae supporting food webs in seagrass meadows. Oecologia 62, 145-149.

Kuo, J., Den Hartog, C., 2001. Seagrass taxonomy and identification key. In: Short, F.T., Coles, R.G. (Eds.), Global Seagrass Research Methods. Elsevier, Amsterdam, pp. 3158.

Laugier, T., Rigollet, V., De Casabianca, M.-L., 1999. Seasonal dynamics in mixed eelgrass

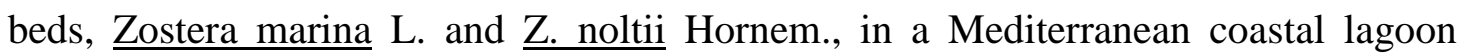
(Thau lagoon, France). Aquat. Bot. 63, 51-69.

Lepoint, G., Nyssen, F., Gobert, S., Dauby, P., Bouquegneau, J.-M., 2000. Relative impact of a seagrass bed and its adjacent epilithic algal community in consumer diets. Mar. Biol. $136,513-518$

Lethbridge, R.C., Borowitzka, M.A., Benjamin, K.J., 1988. The development of an artificial, Amphibolis-like seagrass of complex morphology and preliminary data on its colonization by epiphytes. Aquat. Bot. 31, 153-168. 
Lorenzen, C.J., 1966. A method for the continuous measurement of in vivo chlorophyll concentration. Deep Sea Res. 13, 223-227.

MacIntyre, H.L., Geider, R.J., Miller, D.C., 1996. Microphytobenthos: The ecological role of the "secret garden" of unvegetated, shallow-water marine habitats. I. Distribution, abundance and primary production. Estuaries 19, 186-201.

Main, S.P., McIntire, C.D., 1974. The distribution of epiphytic diatoms in Yaquina estuary, Oregon (U.S.A.). Bot. Mar. 17, 88-89.

Marbà, N., Cebrián, J., Enríquez, S., Duarte, C.M., 1996. Growth patterns of Western Mediterranean seagrasses: species-specific responses to seasonal forcing. Mar. Ecol. Prog. Ser. 133, 203-215.

Mateo, M.A., Cebrián, J., Dunton, K., Mutchler, T., 2006. Carbon flux in seagrass ecosystems. In: Larkum, A.W.D., Orth, R.J., Duarte, C.M. (Eds.), Seagrasses: Biology, Ecology and Conservation. Springer, Dordrecht, pp. 159-192.

Mazzella, L., Russo, G.F., 1989. Grazing effect of two Gibbula species (Mollusca, Archaeogastropoda) on the epiphytic community of Posidonia oceanica leaves. Aquat. Bot. 35, 357-373.

Mazzella, L., Buia, M.C., Spinoccia, L., 1995. Biodiversity of epiphytic diatom community on leaves of Posidonia oceanica. In: Marino, D., Montresor, M. (Eds.), Proceedings of the 13th International Diatom Symposium. Biopress Ltd., Bristol, pp. 241-251.

McLusky, D.S., 1989. The Estuarine Ecosystem. Chapman and Hall, New York, 256 pp.

Menden-Deuer, S., Lessard, E.J., 2000. Carbon to volume relationships for dinoflagellates, diatoms, and other protist plankton. Limnol. Oceanogr. 45, 569-579.

Moncreiff, C.A., Sullivan, M.J., 2001. Trophic importance of epiphytic algae in subtropical seagrass beds: evidence from multiple stable isotope analyses. Mar. Ecol. Prog. Ser. 215, 93-106. 
Moncreiff, C.A., Sullivan, M.J., Daehnick, A.E., 1992. Primary production dynamics in seagrass beds of Mississippi Sound: the contributions of seagrass, epiphytic algae, sand microflora, and phytoplankton. Mar. Ecol. Prog. Ser. 87, 161-171.

Moore, K.A., Short, F.T., 2006. Zostera: biology, ecology, and management. In: Larkum, A.W.D., Orth, R.J., Duarte, C.M. (Eds.), Seagrasses: Biology, Ecology and Conservation. Springer, Dordrecht, pp. 361-386.

Morgan, M.D., Kitting, C.L., 1984. Productivity and utilization of the seagrass Halodule

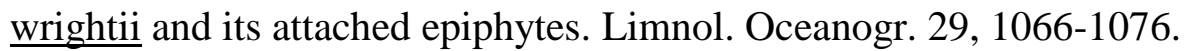

Murray, L., Wetzel, R.L., 1987. Oxygen production and consumption associated with the major autotrophic components in two temperate seagrass communities. Mar. Ecol. Prog. Ser. 38, 231-239.

Orth, R.J., Van Montfrans, J., 1984. Epiphyte-seagrass relationships with an emphasis on the role of micrograzing: a review. Aquat. Bot. 18, 43-69.

Pérez-Lloréns, J.L., Niell, F.X., 1993. Seasonal dynamics of biomass in the intertidal seagrass Zostera noltii Hornem. from Palmones river estuary, Spain. Aquat. Bot. 46, 49-66.

Pergent-Martini, C., Pasqualini, V., Ferrat, L., Pergent, G., Fernandez, C., 2005. Seasonal dynamics of Zostera noltii Hornem. in two Mediterranean lagoons. Hydrobiologia $543,233-243$.

Philippart, C.J.M., 1995a. Seasonal variation in growth and biomass of an intertidal Zostera noltii stand in the Dutch Wadden Sea. Neth. J. Sea Res. 33, 205-218.

Philippart, C.J.M., 1995b. Effect of periphyton grazing by Hydrobia ulvae on the growth of

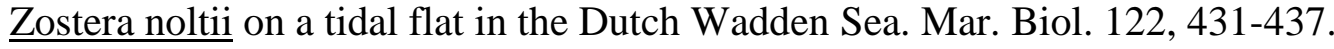

Pigeot, J., 2001. Approche écosystémique de la contamination métallique du compartiment biologique benthique des littoraux charentais : exemple du bassin de MarennesOléron. Ph.D. Thesis, University of La Rochelle, 307 pp. 
Plus, M., Deslous-Paoli, J.-M., Auby, I., Dagault, F., 2001. Factors influencing primary production of seagrass beds (Zostera noltii Hornem.) in the Thau lagoon (French Mediterranean coast). J. Exp. Mar. Biol. Ecol. 259, 63-84.

Poisbleau, M., 2005. Quelle utilisation des hormones dans l'étude des relations de dominance sociale et la compréhension des stratégies d'hivernage? Cas des canards de surface et des bernaches cravants. Ph.D. Thesis, University of Montpellier 2, 344 pp.

Ravail, B., Héral, M., Maestrini, S., Robert, J.-M., 1988. Incidence du débit de la Charente sur la capacité biotique du bassin ostréicole du bassin de Marennes-Oléron. J. Rech. Oceanogr. 13, 48-52.

Reyes, J., Sansón, M., 1997. Temporal distribution and reproductive phenology of the epiphytes on Cymodocea nodosa in the Canary Islands. Bot. Mar. 40, 193-201.

Reyes, J., Sansón, M., Afonso-Carrillo, J., 1998. Distribution of the epiphytes along the leaves of Cymodocea nodosa in the Canary Islands. Bot. Mar. 41, 543-551.

Rincé, Y., 1993. Les diatomées marines de la région de la Basse-Loire: inventaire, distribution spatio-temporelle et devenir expérimental des peuplements naturels d'écosystèmes ostréicoles. Ph.D. Thesis, University of Nantes, 497 pp.

Round, F.E., Crawford, R.M., Mann, D.G., 1990. The Diatoms: Biology and Morphology of the Genera. Cambridge University Press, Cambridge

Schanz, A., Asmus, H., 2003. Impact of hydrodynamics on development and morphology of intertidal seagrasses in the Wadden Sea. Mar. Ecol. Prog. Ser. 261, 123-134.

Schanz, A., Polte, P., Asmus, H., 2002. Cascading effects of hydrodynamics on an epiphytegrazer system in intertidal seagrass beds of the Wadden Sea. Mar. Biol. 141, 287-297.

Sfriso, A., Ghetti, P.F., 1998. Seasonal variation in biomass, morphometric parameters and production of seagrasses in the lagoon of Venice. Aquat. Bot. 61, 207-223. 
Short, F.T., Duarte, C.M., 2001. Methods for the measurement of seagrass growth and production. In: Short, F.T., Coles, R.G. (Eds.), Global Seagrass Research Methods. Elsevier, Amsterdam, pp. 155-182.

Sieburth, J.M., Thomas, C.D., 1973. Fouling on eelgrass (Zostera marina L.). J. Phycol. 9, 4650.

Sommer, U., 2000. Benthic microalgal diversity enhanced by spatial heterogeneity of grazing. Oecologia 122, 284-287.

Struski, C., 2005. Modélisation des flux de matières dans la baie de Marennes-Oléron: Couplage de l'hydrodynamisme, de la production primaire et de la consommation par les huîtres. Ph.D. Thesis, University of La Rochelle, 339 pp.

Trautman, D.A., Borowitzka, M.A., 1999. Distribution of the epiphytic organisms on

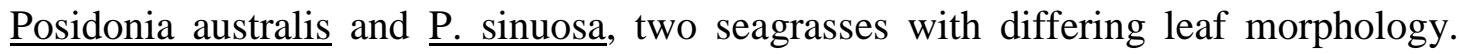
Mar. Ecol. Prog. Ser. 179, 215-229.

Van den Brink, P.J., Hartgers, E.M., Fettweis, U., Crum, S.J.H., Van Donk, E., Brock, T.C.M., 1997. Sensitivity of macrophyte-dominated freshwater microcosms to chronic levels of the herbicide linuron. I. Primary producers. Ecotox. Environ. Safe. 38, 13-24. Van Lent, F., Nienhuis, P.H., Verschuure, J.M., 1991. Production and biomass of the seagrass

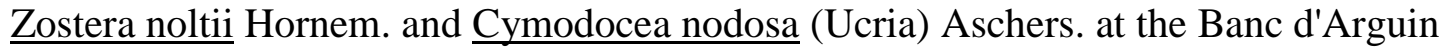
(Mauritania, NW Africa): a preliminary approach. Aquat. Bot. 41, 353-367.

Van Montfrans, J., Orth, R.J., Vay, S.A., 1982. Preliminary studies of grazing by Bittium varium on eelgrass periphyton. Aquat. Bot. 14, 75-89.

Van Montfrans, J., Wetzel, R.L., Orth, R.J., 1984. Epiphyte-grazer relationships in seagrass meadows: Consequences for seagrass growth and production. Estuaries 7, 289-309. 
Vermaat, J.E., Verhagen, F.C.A., 1996. Seasonal variation in the intertidal seagrass Zostera noltii Hornem.: coupling demographic and physiological patterns. Aquat. Bot. 52, 259-281.

Vermaat, J.E., Hootsmans, M.J.M., Nienhuis, P.H., 1987. Seasonal dynamics and leaf growth of Zostera noltii Hornem., a perennial intertidal seagrass. Aquat. Bot. 28, 287-299.

Vermaat, J.E., Beijer, J.A.J., Gijistra, R., Hootsmans, M.J.M., Philippart, C.J.M., Van Den Brink, N.W., Van Vierssen, W., 1993. Leaf dynamics and standing stocks of intertidal Zostera noltii Hornem. and Cymodocea nodosa (Ucria) Ascherson on the Banc d'Arguin (Mauritania). Hydrobiologia 258, 59-72.

Ziegler, S., Benner, R., 1999. Dissolved organic carbon cycling in a subtropical seagrassdominated lagoon. Mar. Ecol. Prog. Ser. 180, 149-160. 
Table 1. Summary of Kruskal-Wallis tests between sampling months for above- (AGP) and below-ground parts (BGP) of Zostera noltii, detrital matter (DM) and microphytobenthos biomass at high (HFS) and low flat stations (LFS).

\begin{tabular}{lccc}
\hline \multicolumn{1}{c}{ Parameters } & Stations & Computed K parameters & p-values \\
\hline AGP biomass & HFS & 19.54 & 0.003 \\
& LFS & 16.05 & 0.007 \\
BGP biomass & HFS & 3.65 & 0.724 \\
& LFS & 12.99 & 0.023 \\
DM mass & HFS & 18.83 & 0.004 \\
& LFS & 15.86 & 0.007 \\
Microphytobenthos biomass & HFS & 8.29 & 0.141 \\
& LFS & 12.47 & 0.029 \\
\hline
\end{tabular}


Table 2. Number and percentage of diatom items counted and measured on Zostera noltii leaves by season at high flat station (HFS) and low flat station (LFS). Percentage of species and densities \pm standard errors (SE) are added for intact cells.

\begin{tabular}{lcccccc}
\hline \multirow{2}{*}{ Parameters } & \multicolumn{2}{c}{ Spring 2006 } & \multicolumn{2}{c}{ Summer 2006 } & \multicolumn{2}{c}{ Fall 2006 } \\
\cline { 2 - 6 } & HFS & LFS & HFS & LFS & HFS & LFS \\
\hline $\mathrm{n}$ total & 2970 & 1744 & 9430 & 1980 & 592 & 193 \\
Intact cells (\%) & 66 & 65 & 72 & 56 & 67 & 54 \\
Cocconeis scutellum (\%) & 79 & 73 & 59 & 84 & 91 & 93 \\
Cocconeis placentula (\%) & - & - & 11 & 5 & - & 1 \\
Not identified (\%) & 21 & 27 & 30 & 11 & 9 & 6 \\
Mean density \pm SE (cells mm m $^{-}$) & $505 \pm 399$ & $381 \pm 435$ & $1641 \pm 1778$ & $507 \pm 598$ & $586 \pm 899$ & $242 \pm 308$ \\
Highest density (cells mm m $^{-2}$ & 1256 & 1287 & 5025 & 1913 & 2066 & 849 \\
Broken cells (\%) & 2 & 3 & 12 & 8 & 9 & 14 \\
Hypovalves (\%) & 24 & 26 & 12 & 26 & 5 & 23 \\
Broken hypovalves (\%) & 8 & 6 & 4 & 9 & 19 & 9 \\
\hline
\end{tabular}


Table 3. Mean biovolumes \pm standard errors (SE) of diatoms $\left(\mu \mathrm{m}^{3}\right)$ and biomass of epiphytes (mg C m${ }^{-2}$ ) at the high (HFS) and low flat station (LFS) in spring (31/05/2006), summer (06/09/06) and fall (09/11/06). Comparison (\%) of epiphyte biomass with microphytobenthos and Zostera noltii leaf biomass.

\begin{tabular}{|c|c|c|c|c|c|c|}
\hline \multirow{2}{*}{ Parameters } & \multicolumn{2}{|c|}{ Spring 2006} & \multicolumn{2}{|c|}{ Summer 2006} & \multicolumn{2}{|c|}{ Fall 2006} \\
\hline & HFS & LFS & HFS & LFS & HFS & LFS \\
\hline Diatom biovolume \pm SE $\left(\mu \mathrm{m}^{3}\right)$ & $62.64 \pm 24.30$ & $72.55 \pm 31.01$ & $46.37 \pm 67.49$ & $93 \pm 120.8$ & $168.37 \pm 69.15$ & $142.1 \pm 70.9$ \\
\hline Epiphyte biomass $\left(\mathrm{mg} \mathrm{C} \mathrm{m}^{-2}\right)$ & 2.59 & 1.56 & 3.97 & 0.48 & 0.98 & 0.09 \\
\hline Comparison with microphytobenthos biomass (\%) & $2.40 \times 10^{-4}$ & $2.11 \times 10^{-4}$ & $3.92 \times 10^{-4}$ & $4.71 \times 10^{-5}$ & $1.23 \times 10^{-4}$ & $1.54 \times 10^{-5}$ \\
\hline Comparison with leaf biomass (\%) & $3.78 \times 10^{-4}$ & $2.02 \times 10^{-4}$ & $6.42 \times 10^{-4}$ & $1.24 \times 10^{-5}$ & $3.25 \times 10^{-4}$ & $6.86 \times 10^{-5}$ \\
\hline
\end{tabular}


Table 4. Microphytobenthos biomass, productions and percent contributions derived from literature.

\begin{tabular}{|c|c|c|c|c|c|c|c|c|c|c|}
\hline \multirow[t]{2}{*}{ Seagrass species } & \multirow[t]{2}{*}{ Location } & \multirow[t]{2}{*}{ Climate } & \multirow{2}{*}{$\begin{array}{c}\begin{array}{c}\text { Seagrass } \\
\text { characteristics }\end{array} \\
\text { Sub. / Int. }\end{array}$} & \multirow{2}{*}{$\begin{array}{c}\text { Measurement } \\
\text { Bel. /Adj. }\end{array}$} & \multirow[t]{2}{*}{ Methods } & \multirow{2}{*}{$\begin{array}{c}\begin{array}{c}\text { Mean } \\
\text { biomass }\end{array} \\
\text { (g C m² flat) }\end{array}$} & \multirow{2}{*}{$\begin{array}{c}\text { Mean gross } \\
\text { production }\end{array}$} & \multirow{2}{*}{$\begin{array}{c}\begin{array}{c}\text { Mean net } \\
\text { production }\end{array} \\
\left(\mathrm{mg} \mathrm{C} \mathrm{m}^{-2} \mathrm{~d}^{-1}\right)\end{array}$} & \multirow[t]{2}{*}{$\begin{array}{l}\text { \% Ecosystem } \\
\text { production }\end{array}$} & \multirow[t]{2}{*}{ Ref. } \\
\hline & & & & & & & & & & \\
\hline Syringodium filiforme & Indian River Lagoon, USA & Tropical & Sub. & Bel. & ${ }^{14} \mathrm{C}$ & - & $17^{\mathrm{a}}$ & - & $33 \%^{\mathrm{a}}$ & 1 \\
\hline Zostera noltii & Island of Sylt, Germany & Temperate & Int. & Adj. & $\mathrm{O}_{2}$ & $0.147^{d}$ & 233 & 183 & $19 \%$ & 2 \\
\hline Thalassia testudinum & Tampa Bay, USA & Tropical & Sub. & Bel. & ${ }^{14} \mathrm{C}$ & - & $180^{\mathrm{b}}$ & - & $10 \%$ & 3 \\
\hline Syringodium filiforme & Indian River Lagoon, USA & Tropical & Sub. & Bel. & ${ }^{14} \mathrm{C}$ & - & $60^{\mathrm{b}}$ & - & $5 \%$ & 3 \\
\hline Ruppia maritima & Cheasapeake Bay, USA & Temperate & Sub. & Adj. & $\mathrm{O}_{2}$ & - & 290 & 219 & $26 \%$ & 4 \\
\hline Zostera marina & Cheasapeake Bay, USA & Temperate & Sub. & Adj. & $\mathrm{O}_{2}$ & - & 616 & 238 & $15 \%$ & 4 \\
\hline Halodule wrightii & Gulf of Mexico, USA & Tropical & Sub. & Bel. & ${ }^{14} \mathrm{C}$ & $2.096^{c}$ & 924 & - & $17 \%$ & 5 \\
\hline Thalassia testudinum & Laguna Madre, USA & Tropical & Sub. & Adj. & $\mathrm{O}_{2} \&$ computation & - & - & 276 & 8 to $36 \%$ & 6,7 \\
\hline Zostera noltii & Island of Sylt, Germany & Temperate & Int. & - & Computation & - & - & 950 & $54 \%^{a}$ & 8 \\
\hline
\end{tabular}

${ }^{\mathrm{a}}$ : computed values (based on 12 hours of production per day), ${ }^{\mathrm{b}}:$ estimated from a figure, ${ }^{\mathrm{c}}$ : computed using a C/Chla ratio of 47.63 (de Jonge, 1980 ), d: computed using a g C/Kj ratio of 42 (McLusky, 1989). Sub.: subtidal bed, Int.: intertidal bed, Bel.: measurement done below the canopy, Adj.: measurement done adjacent to the canopy. References: 1. Heffernan and Gibson, 1983 ; 2. Asmus and Asmus, 1985 ; 3 . Jensen and Gibson, 1986 ; 4. Murray and Wetzel, 1987 ; 5. Daehnick et al., 1992 ; 6. Ziegler and Benner, 1999 ; 7. Kaldy et al., 2002 ; 8 . Asmus and Asmus, 2000. 
Fig. 1.

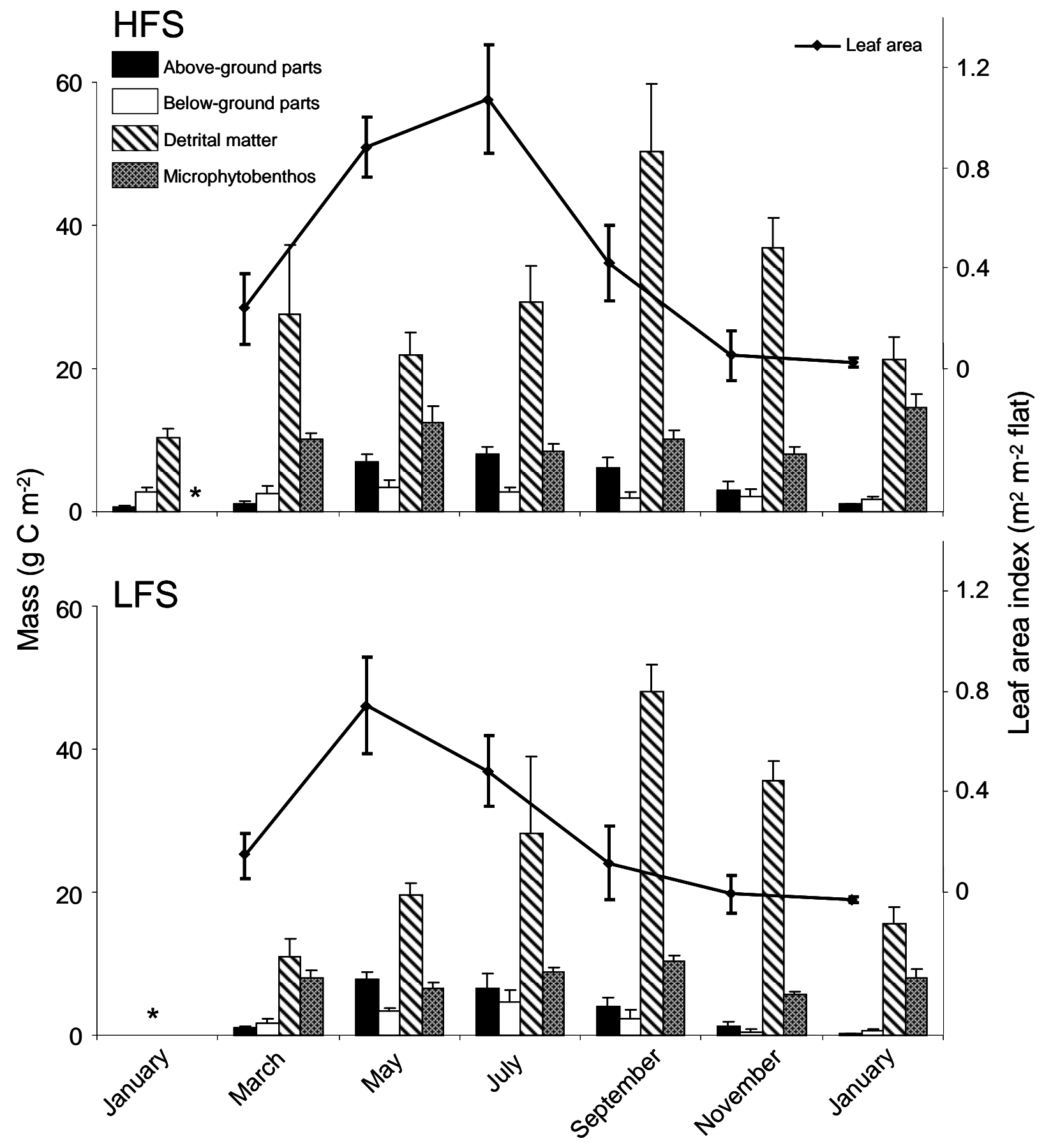


Fig. 2

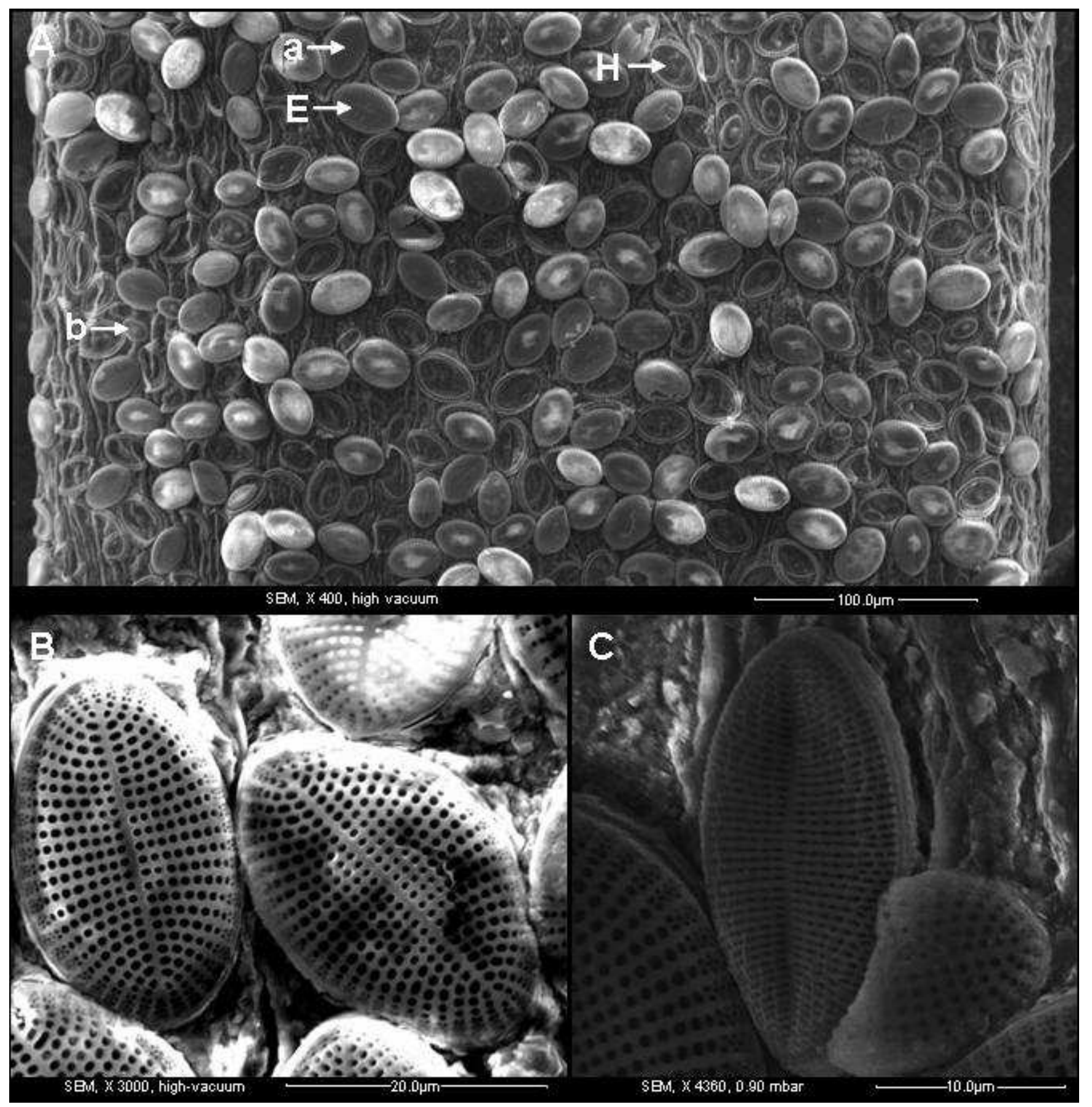


Fig. 3.
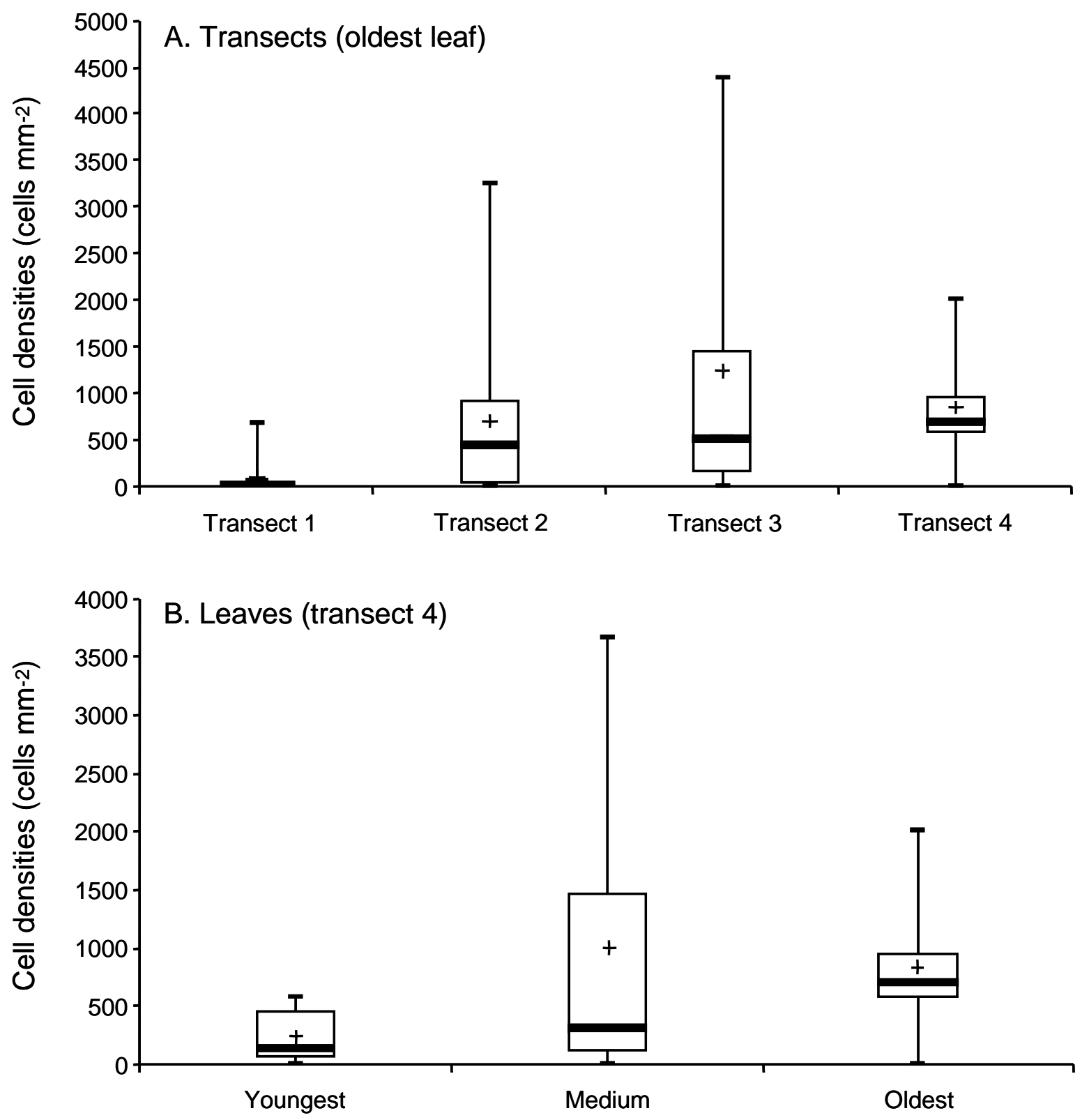


\section{Figures captions}

Fig. 1. Seasonal variation at high (HFS) and low flat station (LFS) of the mean biomass of above- and below-ground parts of Zostera noltii, detrital matter and microphytobenthos (left axis), and Zostera noltii leaf area index (right axis). Error bars represent S.E. and stars lacking data. For microphytobenthos, March and May values were measured in 2007.

Fig. 2. (A) Transect of a Zostera noltii leaf covered by Cocconeis scutellum. E: Entire cells, H: hypovalves. Cells were in a large range of size with lengths from $20 \mu \mathrm{m}$ (a) to $9 \mu \mathrm{m}$ (b). (B) Cocconeis scutellum. (C) $\underline{\text { Cocconeis placentula. }}$

Fig. 3. Box plots of cell densities (cells $\mathrm{mm}^{-2}$ ) on all transects for oldest leaves (A) and on transects 4 (oldest) from youngest, medium and oldest leaves (B). Data from seasons and stations are gathered. Crosses represent means and bars represent medians. 